\title{
Infection of the heart of Pimelodus ornatus (Teleostei, Pimelodidae), by Myxobolus sp. (Myxozoa, Myxobolidae)
}

\author{
Infecção do tecido cardíaco de Pimelodus ornatus (Teleostei, Pimelodidae), \\ por Myxobolus sp. (Myxozoa, Myxobolidae) \\ Edilson Matos ${ }^{1 *}$; Marcela Videira ${ }^{2}$; Michele Velasco ${ }^{1}$; Osimar Sanches ${ }^{3}$; \\ Sergio Carmona de São Clemente ${ }^{4}$; Patricia Matos ${ }^{5}$ \\ ${ }^{1}$ Laboratório de Pesquisa Carlos Azevedo, Universidade Federal Rural da Amazônia - UFRA, Belém, PA, Brasil \\ ${ }^{2}$ Laboratório de Morfofisiologia e Sanidade Animal, Universidade do Estado do Amapá - UEAP, Macapá, AP, Brasil \\ ${ }^{3}$ Laboratório de Patologia Animal, Universidade do Oeste Paulista - UNOESTE, Presidente Prudente, SP, Brasil \\ ${ }^{4}$ Faculdade de Veterinária, Universidade Federal Fluminense - UFF, Niterói, RJ, Brasil. \\ ${ }^{5}$ Laboratório de Pesquisa Edilson Matos, Universidade Federal do Pará - UFPA, Belém, PA, Brasil
}

Received June 13, 2014

Accepted September 22, 2014

\begin{abstract}
The phylum Myxozoa Grassé, 1970, consists of a heterogenous group of around 50 genera that are worldwide disseminated in a wide variety of aquatic media. In the present study, 43 specimens of Pimelodus ornatus were collected from an adjacent area to the Cachoeira do Arari municipality on Marajó Island, in the Brazilian state of Pará, in 2013. Macroscopic analysis showed the presence of whitened plasmodia located in the cardiac muscle and also in the region between the bulbus arteriosus and atrium cordis. Microscopic analysis on the parasitized tissues revealed spores that were typically piriform, with the anterior portion slightly narrower than the posterior end. The spore valves were symmetrical. The present species is placed in the genus Myxobolus Butschli, 1882, because of the presence of a pair of equal polar capsules in each spore. The prevalence of parasitism observed was 13.9\% (6/43). This research note reports the first occurrence of Myxobolus as a parasite of the heart in the teleostean fish P. ornatus in the Amazon region and confirms the occurrence of secondary myocarditis in this fish, caused by parasitism by Myxobolus sp. The rarity of this parasitic species of Myxobolus at this tissue site, associated with other spore morphology characteristics in the fish, suggests that it is an undescribed species.
\end{abstract}

Keywords: Myxozoa, Myxobolus sp., cardiac muscle, Pimelodus ornatus.

\section{Resumo}

O filo Myxozoa Grassé, 1970, consiste em um grupo heterogêneo de cerca de 50 gêneros que são disseminados em todo o mundo em uma grande variedade de meios aquáticos. No presente estudo, quarenta e três espécimes de Pimelodus ornatus foram coletados a partir de uma área adjacente à cidade de Cachoeira do Arari, na Ilha do Marajó, no Estado do Pará, em 2013. À análise macroscópica verificou-se a presença de plasmódios esbranquiçados, localizados no músculo cardíaco e também na regiáo entre o bulbus arteriosus e o atrium cordis. A análise microscópica dos tecidos parasitados revelou esporos que eram tipicamente piriformes, com a porção anterior um pouco mais estreita do que a extremidade posterior, sendo suas válvulas simétricas. A prevalência do parasitismo observada foi de 13,9\% (6/43). Esta nota de pesquisa relata a primeira ocorrência de Myxobolus como um parasita do coração no peixe teleósteo P. ornatus, na Regiâo Amazônica e, confirma a ocorrência de miocardite secundária causada por esse parasitismo. A raridade da ocorrência de Myxobolus sp. neste tecido, associado a outras características morfológicas dos esporos no peixe, sugere que é uma espécie não descrita.

Palavras-chave: Myxozoa, Myxobolus sp., tecido cardíaco, Pimelodus ornatus.

*Corresponding author: Edilson Matos, Laboratório de Pesquisa Carlos Azevedo, Universidade Federal Rural da Amazônia - UFRA, Avenida Presidente Tancredo Neves, 2501, Montese, CEP 66077-901, Belém, PA, Brasil, e-mail: edilson.matos9@gmail.com 
The phylum Myxozoa Grassé, 1970, consists of a heterogenous group of around 50 genera (LOM \& DYKOVÁ, 1992) that are worldwide disseminated in a wide variety of aquatic media (both freshwater and saltwater). Most of these parasites are considered to be pathogenic acting on many different tissues and organs of fish, such as the liver, kidneys, gills, gonads, intestine, skin and others (LOM \& DYKOVÁ, 2006).

Among the myxosporidians, the genus Myxobolus is prominent. This has the following principal characteristics: ellipsoid, oval or rounded spores formed by two valves, two polar capsules, generally piriform, each with a polar filament, bilateral symmetry and mono or binucleated protoplasm (EIRAS et al., 2005).

In Brazil, more than 20 new species of parasites belonging to the genus Myxobolus Bütschli, 1882, have been described, mainly in the Amazon region. Most recently, Myxobolus myleus was described in the gallbladder of Myleus rubripinnis collected near the municipality of Oriximiná in the state of Pará (PA), Brazil (AZEVEDO et al., 2012), and Myxobolus sp. in the palate of Gobioides broussonnetii, from Marajó Island, PA, Brazil (VELASCO et al., 2012).

This article reports the first occurrence of Myxobolus sp. in the heart of P. ornatus Kner, 1858, from the Arari River (Marajó Island, PA, Brazil), with histopathological descriptions of the parasite's interaction with the host's heart tissue and morphological descriptions of the spores under an optical microscope.

Forty-three specimens of $P$. ornatus (brazilian common name "mandii") were collected from an area adjacent to the municipality of Cachoeira do Arari ( $\left.01^{\circ} 00^{\prime} \mathrm{S} / 48^{\circ} 57^{\prime} \mathrm{W}\right)$ on Marajó Island, in the Brazilian state of Pará, in 2013. The live specimens were taken to the Carlos Azevedo Research Laboratory at UFRA and were kept in an aquarium at $28-30{ }^{\circ} \mathrm{C}$. The fish were then anesthetized with tricaine methanesulfonate (MS222; Sandoz Laboratories) at a concentration of $50 \mathrm{mg} / \mathrm{L}$ and were dissected using a stereomicroscope appropriate for analysis on parasites. For optical microscopy, small fragments (approximately $0.5 \mathrm{~cm}$ ) of the parasitized tissue from the fish heart were fixed in Davidson solution (neutral buffered formalin, glacial acetic acid, 95\% ethyl alcohol and distilled water) for $24 \mathrm{~h}$ and were then processed and stained with hematoxylin and eosin, ZiehlNeelsen, toluidine blue and Masson's trichrome (LUNA, 1968). The measurements of spores were made in accordance with Lom \& Dyková (1992) under an optical microscope using a Zeiss Primo Star photographic camera (Zeiss AxioCam ERC 5s) and the AxioVision 5.1 software.

Macroscopic analysis showed the presence of whitened plasmodia located in the cardiac muscle and also in the region between the bulbus arteriosus and atrium cordis of the heart (Figure 1).

Microscopic analysis on the parasitized tissues revealed spores that were typically piriform with the anterior portion slightly narrower than the posterior end (Figure 2 and inset). The spore valves were symmetrical, and had two equal polar capsules. The dimensions of the spores are described in detail in Table 1, with comparisons with other parasites of the genus Myxobolus that have been described in the Amazon region.

The distinctions between the different species of the genus Myxobolus are primarily based on the morphological structure of the spore, and particularly its size and shape. The present parasite was placed in the genus Myxobolus Butschli, 1882, because of the presence of a pair of equal polar capsules in each spore (LOM \& DYKOVÁ, 2006). The prevalence of parasitism observed was $13.9 \%(6 / 43)$.

Histological sections through the heart revealed that the spores can disperse into the lumen and wall of the bulbus arteriosus. The presence of free spores in other organs is the result of this dispersal and these organs should not be interpreted as alternative sites of plasmodial development.

The samples sectioning the heart also revealed multifocal infection by Myxobolus sp, organized in the pericardium plasmodia

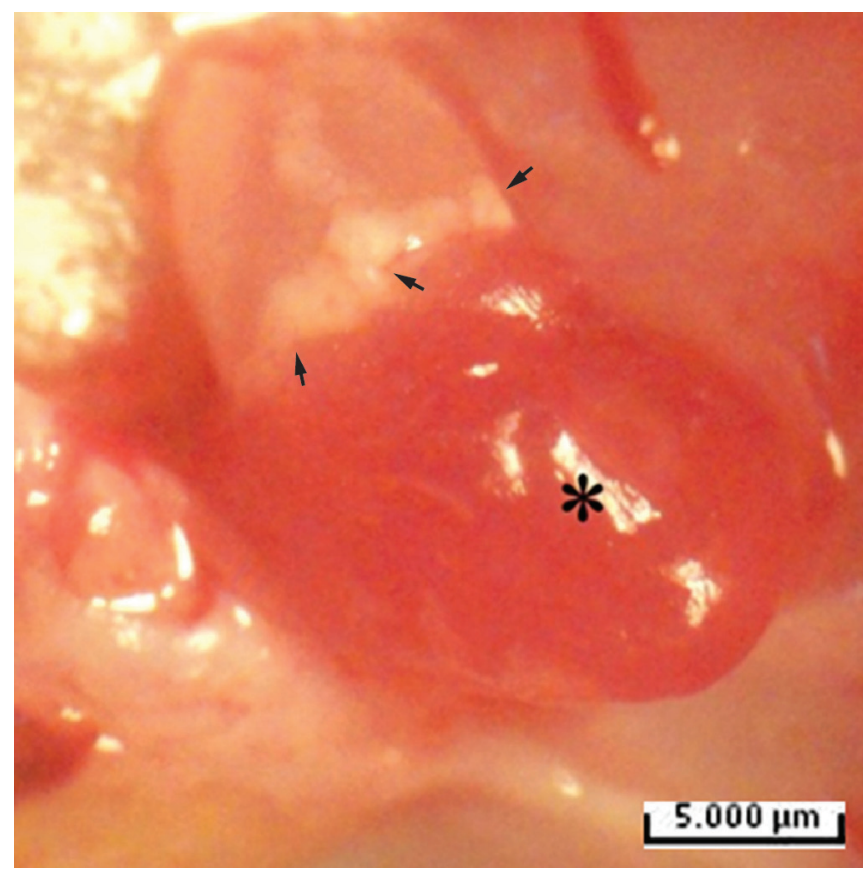

Figure 1. Myxobolus sp. plasmodia (arrow) in the bulbus arteriosus and atrium cordis of the heart $\left(^{*}\right)$.

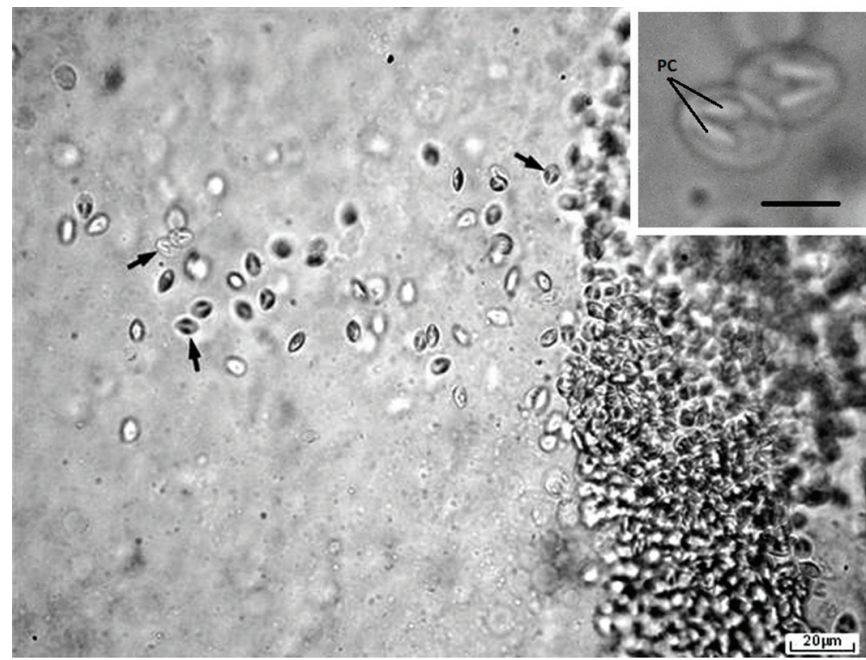

Figure 2. Microphotograph of Myxobolus sp. spores examined in fresh preparation (arrows). Inset: Myxobolus spores containing two polar capsules (PC) (scale bar $5 \mu \mathrm{m})$. 
and bulbus arteriosus (Figures 3A, B). The plasmodia had a thin capsule of collagen fibers and there were numerous specimens of the parasite inside the plasmodia (Figures 3C, D). There was a slight inflammatory reaction around the plasmodia. Multifocal degeneration of myocardial fibers around the infected area was also observed (Figure 3E).

Table 1. Comparative measurements (in mm)* of the spores from Myxobolus spp. parasitizing fishes from Amazonian Brazilian fauna.

\begin{tabular}{|c|c|c|c|c|c|c|c|c|c|}
\hline Myxobolus spp. & $\begin{array}{c}\text { Location of } \\
\text { plasmodia }\end{array}$ & SL & SW & ST & PCL & PCW & PFC & Hosts country / region & Authors \\
\hline M. heckelii & Gill filaments & 12.7 & 6.6 & 4.0 & 2.9 & 1.7 & $4-5$ & $\begin{array}{l}\text { Centromochlus heckelii I } \\
\text { Amazon river }\end{array}$ & Azevedo et al. (2009) \\
\hline M. myleus & Gallbladder / bile & 19.3 & 8.3 & 4.0 & 13.2 & 3.0 & $19-21$ & $\begin{array}{l}\text { Myleus rubripinnis / } \\
\text { Amazon river }\end{array}$ & Azevedo et al. (2012) \\
\hline Myxobolus sp 1 & Palate & - & - & - & - & - & - & $\begin{array}{l}\text { Gobioides broussonnetii / } \\
\text { Marajó Island }\end{array}$ & Velasco et al.(2012) \\
\hline Myxobolus sp 2 & $\begin{array}{l}\text { Bulbus arteriosus / } \\
\text { cardiac muscle }\end{array}$ & $\begin{array}{l}8 \pm \\
0.2\end{array}$ & $\begin{array}{c}5.8 \pm \\
0.4\end{array}$ & $\begin{array}{c}3.4 \pm \\
0.2\end{array}$ & $\begin{array}{c}3.6 \pm \\
0.3\end{array}$ & $\begin{array}{c}1.2 \pm \\
0.2\end{array}$ & - & $\begin{array}{l}\text { Pimelodus ornatus / } \\
\text { Marajó Island }\end{array}$ & Present study ${ }^{* *}$ \\
\hline
\end{tabular}

* SL, spore length; SW, spore width; ST, spore thickness; PCL, polar capsule length; PCW, polar capsule width; PFC, polar filament coils; -, without data; ** The measurements of spores were made high magnification.
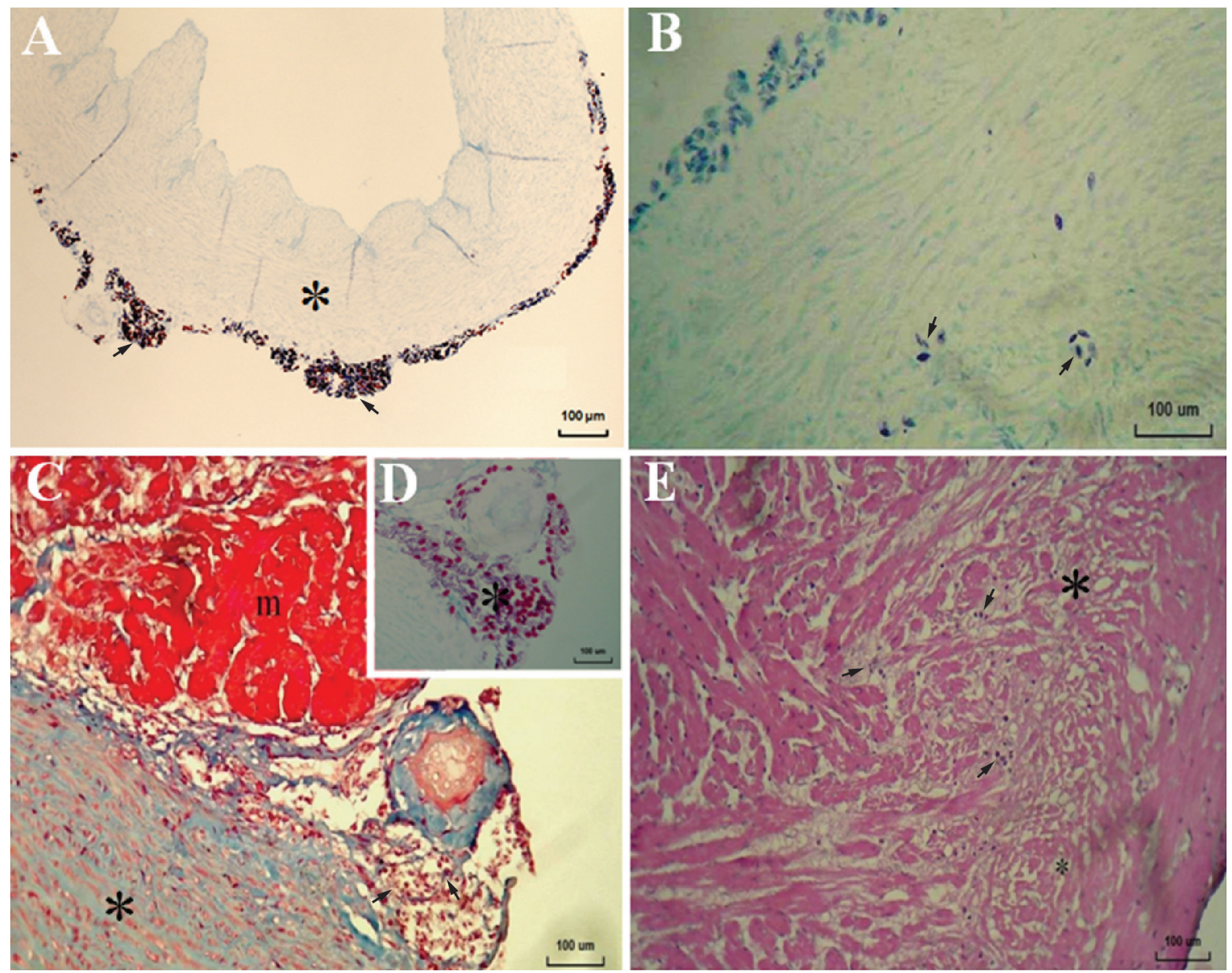

Figure 3. (A) Myxobolus sp. plasmodia (arrows) containing mature spores among the connective tissue cells forming the wall of the bulbus arteriosus $\left(^{*}\right)$. (B) Bulbus arteriosus being invaded by spores of Myxobolus sp. (arrows) (toluidine blue). (C) Myxobolus sp. plasmodia containing mature spores (arrow) located in the serosa (pericardium) covering the wall of the bulbus arteriosus $\left(^{*}\right)$ and cardiac muscle (m) (Masson's trichrome stain). (D) Myxobolus sp. mature spores $\left({ }^{*}\right)$ located in the serosa (pericardium) (Masson's trichrome stain). (E) Section of heart muscle at the junction with bulbus arteriosus, especially fiber necrosis $\left(^{*}\right)$ and multifocal inflammatory infiltrate (arrows), featuring myocarditis (HE stain). 
Other occurrences of Myxobolus have been described in the Amazon region (AZEVEDO et al., 2002; CASAL et al., 2002; AZEVEDO et al., 2009; AZEVEDO et al., 2012; VELASCO et al., 2012), but there had not previously been any mention of myxosporidiosis in the hearts of fish in this region.

In this regard, the tissue specificity for this species of Myxobolus, in the serosa (pericardium), bulbus arteriosus and cardiac muscle, was similar to that of Myxobolus bulbocordis (MASOUMIAN et al., 1996), which was also reported from the serosa of the atrium and bulbus cordis.

This research note reports the first occurrence of Myxobolus as a parasite of the heart in the Amazon region and confirms the occurrence of secondary myocarditis in P. ornatus associated with parasitism by Myxobolus sp. The rarity of this parasitic species of Myxobolus at this tissue site, associated with other spore morphology characteristics in the fish, suggests that it is an undescribed species.

\section{Acknowledgements}

The authors are grateful to the Dr. David Elliff for the translation and revision of the manuscript, Coordenação de Aperfeiçoamento de Pessoal de Nível Superior (CAPES), Conselho Nacional de Desenvolvimento Científico e Tecnológico (CNPq) (Edital Universal 2011), FAPESPA, Sistema de Autorização e Informação em Biodiversidade (SISBIO) / Instituto Chico Mendes de Conservação e Biodiversidade (ICMBIO) / Instituto Brasileiro do meio ambiente e dos Recursos Naturais Renováveis (IBAMA) - Licença 27119. The various aspects of this work complied with the current laws of the countries in which they were carried out. We would also like to thank the referees for their comments and suggestions.

\section{References}

Azevedo C, Corral L, Matos E. Myxobolus desaequalis n. sp. (Myxozoa, Myxosporea), parasite of the Amazonian freshwater fish, Apteronotus albifrons (Teleostei, Apteronotidae). J Eukaryot Microbiol 2002; 49(6):
485-488. http://dx.doi.org/10.1111/j.1550-7408.2002.tb00233.x. PMid:12503685

Azevedo C, Casal G, Matos P, Ferreira I, Matos E. Light and electron microscopy of the spore of Myxobolus heckelii n. sp. (Myxozoa), parasite from the Brazilian fish Centromochlus heckelii (Teleostei, Auchenipteridae). J Eukaryot Microbiol 2009; 56(6): 589-593. http:// dx.doi.org/10.1111/j.1550-7408.2009.00441.x. PMid:19883448

Azevedo C, São Clemente SC, Casal G, Matos P, Alves Â, Al-Quraishy $\mathrm{S}$, et al. Myxobolus myleus n. sp. infecting the bile of the Amazonian freshwater fish Myleus rubripinnis (Teleostei: Serrasalmidae): morphology and pathology. Syst Parasitol 2012; 82(3): 241-247. http://dx.doi. org/10.1007/s11230-012-9360-0. PMid:22711511

Casal G, Matos E, Azevedo C. Ultrastructural data on the spore of Myxobolus maculatus n. sp. (phylum Myxozoa), parasite from the Amazonian fish Metynnis maculatus (Teleostei). Dis Aquat Organ 2002; 51(2): 107-112. http://dx.doi.org/10.3354/dao051107. PMid:12363082

Eiras JC, Molnár K, Lu YS. Synopsis of the species of Myxobolus Butschli, 1882 (Myxozoa: Myxosporea: Myxobolidae). Syst Parasitol 2005; 61(1): 1-46. http://dx.doi.org/10.1007/s1 1230-004-6343-9. PMid:15928990

Lom J, Dyková I. Myxozoan genera: definition and notes on taxonomy, life-cycle terminology and pathogenic species. Folia Parasitol 2006; 53(1): 1-36. http://dx.doi.org/10.14411/fp.2006.001. PMid:16696428

Lom J, Dyková I. Protozoan parasites of fishes. Amsterdam: Elsevier; $1992.315 \mathrm{p}$.

Luna LG. Manual of histologic staining methods of the Armed Forces Institute of pathology. 3rd ed. Washington: American Registry of Pathology; $1968.258 \mathrm{p}$.

Masoumian M, Baska F, Malnár K. Description of Myxobolus bulbocordis sp. Nov. (Myxosporea: Myxobolidae) from the heart of Barbus sharpeyi (Günther) and histopathological changes produced by the parasite. J Fish Dis 1996; 19(1): 15-21. http://dx.doi.org/10.1111/j.1365-2761.1996. tb00115.x.

Velasco M, Matos P, Sanches O, Clemente SCS, Videira M, Santos P, et al. Necrotizing myositis associated with parasitism by Myxobolus sp. (Myxozoa) in the palate of the violet goby,Gobioides broussonnetii (Gobiidae), from Marajó Island, Brazil. Aquaculture 2012; 358-359: 129-131. http://dx.doi.org/10.1016/j.aquaculture.2012.06.033. 